\title{
Stolica Apostolska w relacjach z I Rzecząpospolitą pierwszej połowy XVII stulecia
}

\author{
Henryk Litwin, Chwała Pólnocy. Rzeczpospolita w europejskiej \\ polityce Stolicy Apostolskiej w pierwszej połowie XVII wieku (1599- \\ -1648), Lublin 2013, $332 \mathrm{s.}$ \\ Dariusz Kuźmina, Wazowie a Kościól w Rzeczypospolitej, \\ Warszawa 2013, $358 \mathrm{~s}$. \\ Paweł Duda, Polityka zagraniczna Rzeczypospolitej w ocenie \\ dyplomacji papieskiej w latach 1623-1535 [w druku].
}

Formuła niniejszego tekstu wiąże się z trzema pozycjami historycznymi, które $\mathrm{z}$ różnych względów naukowych znalazły się $\mathrm{w}$ bezpośrednim kręgu moich zainteresowań. Chodzi o dwie monografie, które ukazały się w ostatnim czasie: Chwała Pótnocy. Rzeczpospolita w europejskiej polityce Stolicy Apostolskiej w pierwszej połowie XVII wieku (1599-1648) Henryka Litwina, opublikowana w lubelskim wydawnictwie KUL w 2013 roku i Wazowie a Kościół w Rzeczypospolitej Dariusza Kuźminy (Warszawa 2013) ${ }^{1}$ oraz o pracę Pawła Dudy zatytułowaną Polityka zagraniczna Rzeczypospolitej w ocenie dyplomacji papieskiej w latach 1623-15352.

W wymienionych pozycjach przewijają się interesujące wątki tematyczne naświetlające problem relacji Kościoła i państwa poprzez pryzmat oddziaływań Stolicy Apostolskiej, a także opisujące stosunki dynastia Wazów - Kościół w Rzeczypospolitej.

${ }^{1}$ Ta pozycja ukazała się w Oficynie Wydawniczej ASPRA-JR, na stronie tytułowej widnieje zapis: Instytut Informacji Naukowej i Studiów Bibliologicznych, Wydział Historyczny Uniwersytet Warszawski.

${ }^{2}$ To rozprawa doktorska napisana pod kierunkiem prof. Ryszarda Skowrona i obroniona w lipcu 2014 roku w Instytucie Historii Wydziału Nauk Społecznych Uniwersytetu Śląskiego w Katowicach. Praca w przygotowaniu do druku. Składam podziękowanie Autorowi za wyrażenie zgody na cytowanie pracy. 
Polityka wyznaniowa trzech królów z dynastii Wazów - Zygmunta III, Władysława IV i Jana Kazimierza została dość wyczerpująco i wszechstronnie przedstawiona w literaturze przedmiotu, jednak nadal pozostaje sporo kwestii wartych dalszego omówienia ${ }^{3}$. Wyraźnie nowe kierunki badań zaproponowane przez Henryka Litwina, Dariusza Kuźminę oraz historyka reprezentującego najmłodsze pokolenie, Pawła Dudę, z pewnością będą sprzyjać wielu dyskusjom w przyszłości.

Dariusz Kuźmina podjął się w swej rozprawie próby odpowiedzi na wiele interesujących pytań: o wychowanie młodych przedstawicieli rodziny królewskiej, przede wszystkim przez zakonników z Towarzystwa Jezusowego, o wpływ przedstawicieli hierarchii katolickiej na działalność rodu panującego, rolę duchownych z dynastii Wazów czy kwestię wzajemnego oddziaływania stanów sejmujących, które tworzyły ową „monarchię mixta", w ten sposób charakteryzowaną przez wielu obserwatorów z zewnątrz. Autor słusznie podkreślił, że I Rzeczpospolita była dla ówczesnej Europy „państwem bez stosów”.

Nasz kraj sprzed stuleci stanowił w istocie mozaikę religijną, w której przeważały, co oczywiste, wyznania chrześcijańskie. Ale do katolików, prawosławnych, unitów dołączyli luteranie, kalwini, bracia czescy i nawet arianie - nie znajdujący nigdzie indziej, za wyjątkiem jeszcze Siedmiogrodu, miejsca w Europie.

Autor monografii poświęconej Wazom i ich relacjom z Kościołem zwraca uwagą na rolę i znaczenie soboru trydenckiego i jego postanowień związanych z wytyczeniem kierunków oddziaływania Kościołów lokalnych. „Episkopaty europejskie wkroczyły na drogę kreowania polityki wyznaniowej w swoich państwach głównie poprzez wprowadzenie reform trydenckich" (Kuźmina 2013: 9). W Rzeczypospolitej przedstawiciele hierarchii kościelnej związani byli z systemem władzy, najbardziej spektakularny przejaw tych powiązań to ważne miejsce zasiadania w senacie i funkcja interreksa. Stolica Apostolska przywiązywała wielką wagę do tego, by w wyniku wyborów na tronie królewskim zasiadł król katolik.

\footnotetext{
${ }^{3}$ Stan badań nad dynastią Wazów w Polsce: Kuźmina 2013: 13-15.

${ }^{4}$ Termin ten $\mathrm{w}$ istocie powstał i został powszechnie przyjęty w historiografii i publicystyce dzięki prof. Januszowi Tazbirowi, który zatytułował tak swoją książkę Państwo bez stosów. Szkice z dziejów tolerancji religijnej w Polsce XVI i XVII w., opublikowaną w roku 1967. Doczekała się ona w następnych latach wielu wznowień.
} 
Drugi ważki element stanowiły kwestie edukacji. Rola jezuitów w nowej, potrydenckiej rzeczywistości była nie do przecenienia. Dość przypomnieć o znakomitej uczelni prawosławnej - Kolegium Kijowsko-Mohylańskim wzorowanym na podstawach nauczania zaproponowanych przez jezuitów. Wzmianki na ten temat brakuje, niestety, w pracy profesora Kuźminy. Autor zwrócił natomiast uwagę na wiele aspektów związanych z wychowaniem i tradycją katolicką przedstawicieli dynastii Wazów w Rzeczypospolitej, ukazując jednocześnie wiele elementów ich polityki uwzględniających racje przedstawicieli innych wyznań aniżeli katolickie.

Nieco uwagi poświęcono systemowi klientelizmu: obejmowanie urzędów biskupich i administracyjnych w państwie odzwierciedlało stosunki panujące między patronem a klientem. „Dla hierarchów Kościoła praca na rzecz władcy była w czymś w rodzaju kontraktu" - podkreśla Dariusz Kuźmina (2013: 314). Ocenia on ponadto, że znaczenie duchownych w zarządzaniu państwem w XVII wieku było duże i przynosiło dobre skutki.

Politykę wyznaniową trzech Wazów, z zastrzeżeniem, że w gruncie rzeczy wyznaczała ją szlachta, Autor ocenił pozytywnie. Wysokie noty otrzymało zwołanie Colloqium charitativum, będące świadectwem tolerancji religijnej w Polsce. Unia brzeska, która dokonała się za czasów Zygmunta III Wazy, miała osłabić prawosławie na wschodzie Rzeczypospolitej, ale też jej celem było wzmocnienie wpływów Rzymu i katolicyzmu. Analizując postawy dwunastu prymasów (od Stanisława Karnkowskiego po Mikołaja Prażmowskiego), którzy sprawowali urząd w czasie panowania trzech królów z dynastii Wazów, Kuźmina przyznał, że to oni, wraz z biskupami, kreowali politykę wyznaniową w kraju. Portret hierarchii katolickiej można w przyszłości narysować znacznie wyraźniej, kładąc większy nacisk na jej powiązania z Rzymem (Stolicą Apostolską), a może nawet pokusić się o wizerunek zbiorowy.

Być może niedostatek tej perspektywy był przyczyną niezwrócenia uwagi na istotne zdarzenie: w roku 1643 przedstawiciele senatu i episkopatu wspólnie wystąpili w obronie króla i Rzeczypospolitej przeciwko Stolicy Apostolskiej. Był to moment niewątpliwego kryzysu w stosunkach z papiestwem. Poważnym powodem była postawa przedstawiciela Stolicy Apostolskiej, nuncjusza Maria Filonardiego, który piastował swój urząd 
w Rzeczypospolitej w latach 1636-1643 (Chynczewska-Hennel 2003, 2006ab).

Rosnące od lat 40. XVII wieku nieporozumienia nuncjusza z królem Władysławem IV Wazą doprowadziły w październiku 1643 roku do opuszczenia przez Filonardiego Rzeczypospolitej jako persona non grata. Był to ewenement w kontaktach dyplomatycznych państwa i Kościoła w epoce nowożytnej; dopiero wybór nowego papieża Innocentego X, po śmierci Urbana VIII Barberiniego w 1644 roku, spowodował wznowienie stosunków dyplomatycznych.

Nie wchodząc w szczegóły, trzeba podkreślić, że jedną z istotnych przyczyn narastającego konfliktu było przywrócenie hierarchii prawosławnej i pozycja Kościoła prawosławnego w Rzeczypospolitej. Niepokój budziło zatwierdzenie przez Władysława IV Wazę konstytucji Religia grecka w roku 1635, czemu nie był w stanie przeciwstawić się już Honorato Visconti, poprzednik Filonardiego. Do apogeum konfliktu doszło w marcu 1643 roku. Wtedy to przejęto listy nuncjusza Filonardiego, w których miał on szkalować króla jako protektora „heretyków” i „schizmatyków”.

Ważnym aktem w historii tego sporu było pismo do papieża Urbana VIII wystosowane przez senatorów Rzeczypospolitej z datą 27 marca 1643 roku (Epistola ad Papam Urbanum VIII 1864: 277-280). Czołowi reprezentanci życia politycznego ówczesnej Rzeczypospolitej zaprotestowali przeciwko obrażaniu majestatu królewskiego, a tym samym majestatu Rzeczypospolitej. W argumentacji odpierano szereg zarzutów związanych z wybieralnością królów, rolą sejmu, współrządzeniem szlachty. Wyraźnie podkreślano wagę polskiej tolerancji, dzięki której zamiast „,nienawiści inkwizycji”, prowadzącej do rozlewu krwi, zaprowadzony został w Polsce pokój religijny. $Z$ dumą pisano, że nasi królowie stosują do nawracania „heretyków” skuteczniejsze metody aniżeli miecz. Stanowczo proszono papieża o odwołanie z Polski nuncjusza Filonardiego. List ten podpisali: Maciej Łubieński (1572-1652), arcybiskup metropolita gnieźnieński (Kuźmina 2013: 120-121), Andrzej Szołdrski (1583-1650) biskup poznański, Aleksander Trzebiński (zm. 1644) biskup przemyski, podkanclerzy koronny (od marca 1643, po Ossolińskim), Andrzej Gembicki (1585-1657) biskup łucki, Marcjan Tryzna (zm.1643) podkanclerzy litewski, Stanisław Koniecpolski (ok. 1594-1646) kasztelan krakowski, hetman wielki koronny, Krzysztof Chodkiewicz (zm. 1652) wojewoda wileński, Jakub 
Sobieski (1590-1646) wojewoda ruski, Jerzy Ossoliński (1595-1650) kanclerz wielki koronny, Albrycht Stanisław Radziwiłł (1593-1656) kanclerz wielki litewski, Jerzy Lubomirski (1616-1667) marszałek sejmu.

Jak widać, protest przeciwko dyplomacie papieskiemu podpisali przedstawiciele hierarchii Kościoła rzymskokatolickiego wraz z czołowymi świeckimi dostojnikami państwowymi. Nie miejsce tu na dalsze rozważania, jedno wydaje się jednak kwestią zasadniczej wagi: sprawa tak zwanej racji stanu, którą reprezentowała, jak uważam, elita senatorska występująca solidarnie w obronie godności króla i Rzeczypospolitej (Chynczewska-Hennel 2012: 143-152). Perspektywę „rzymską”, pominiętą w pracy Dariusza Kuźminy, uzupełniają w znacznej mierze dwie inne pozycje wymienione na wstępie.

Interesująca rozprawa Pawła Dudy pod tytułem Polityka zagraniczna Rzeczypospolitej w ocenie dyplomacji papieskiej w latach 1623-1635 opiera się na solidnej bazie źródłowej, którą stanowi korespondencja stałych dyplomatów papieskich, nuncjuszy na dworach europejskich. Korespondencja ta, na którą składają się w głównej mierze relacje nuncjuszy z Sekretariatem Stanu oraz korespondencja zwrotna z Rzymu - do dziś nie jest wykorzystana w pełni, spora część materiału spoczywa nadal w archiwach Watykanu i Rzymu. Tymczasem jest to nieocenione źródło, pozwalające na nowoczesną konstrukcję narracyjną historii I Rzeczypospolitej w jej złożonych uwarunkowaniach politycznych w Europie, we wszechstronniejszym i pełniejszym widzeniu wielu ważnych problemów.

Pytanie, które zadał Paweł Duda we wstępie pracy, brzmi następująco: ,jak Stolica Apostolska w pierwszej fazie pontyfikatu Urbana VIII, a więc w latach 1623-1635, oceniała politykę zagraniczną Rzeczypospolitej Obojga Narodów i w jakim stopniu starała się na nią wpływać?" (Duda 2014: 6).

Autor rozpoczyna rozważania od omówienia sytuacji politycznej w pierwszych latach pontyfikatu Urbana VIII w Europie. Był to moment względnej stabilizacji w wojnie trzydziestoletniej, sytuacja polityczna Rzeczypospolitej Obojga Narodów także była raczej stabilna. Przypomnijmy, że zawarto rozejm w Dywilinie, kończący wieloletnie wojny z Moskwą. W 1621 roku pod Chocimiem podpisano traktat pokojowy, który stabilizował relacje z Turcją. Problemem pozostawała wówczas Szwecja i z tym właśnie wiązała się próba realizacji planu królewskiego Zygmunta 
III Wazy, któremu marzyło się odzyskanie dziedzicznego państwa. Sprawy szwedzkie wchodziły w orbitę zainteresowań nuncjusza Giovanniego Battisty Lancellottiego.

Bardzo ciekawie przedstawił Duda działania dyplomacji papieskiej w sprawie wojny polsko-szwedzkiej drugiej połowy lat dwudziestych XVII wieku. Wydawało się, że polski udział w wojnie trzydziestoletniej został w historiografii dość dobrze opracowany (prace Radosława Lolo, Zbigniewa Anusika), ale dopiero badania Pawła Dudy pokazały z pełną wyrazistością, jaką rolę w tym międzynarodowym konflikcie odegrała dyplomacja papieska. Autor słusznie wskazuje, że w Rzymie doskonale zdawano sobie sprawę, jak ważna w przebiegu starcia Ligi Katolickiej z protestantami na terytorium Niemiec była konfrontacja Wazów w Prusach. Hiszpańska i austriacka linia Habsburgów brała pod uwagę udział Rzeczypospolitej w realizacji swych planów. Powyższy przykład dobrze pokazuje skomplikowane międzynarodowe uwarunkowania, w jakich papiestwo świetnie się odnajdowało, sprawnie prowadząc politykę zagraniczną poprzez dobrze zorganizowaną sieć dyplomatów, znakomicie przygotowanych do pełnionych zadań.

Po Lancellottim kolejnym nuncjuszem, który przejął obserwację sceny politycznej w Europie Środkowo-Wschodniej, zwłaszcza na północy, był Antonio Santacroce. Opisując sporządzone przez legata dokumenty, Paweł Duda trafnie uzupełnił swoje studium o informacje nuncjuszy wiedeńskich obawiających się ewentualnej szwedzkiej hegemonii na Bałtyku, która mogła zagrozić Habsburgom. Nie dziwi zatem poparcie dyplomacji papieskiej dla współpracy polsko-habsburskiej w tym okresie, tj. w latach 1626-1629.

Nieco inaczej przedstawiała się kwestia poparcia polityki Rzeczypospolitej w latach 1630-1632, gdyż, zdaniem Pawła Dudy, w tym czasie Stolica Apostolska w mniejszym stopniu postrzegała państwo polsko-litewskie jako wykonawcę swych planów politycznych (Duda 2014: 209). Zmiana kierunku politycznego Rzymu zbiegła się z desygnowaniem na miejsce Santacrocego nowego nuncjusza - Honorata Viscontiego - który czynił zabiegi, by polski monarcha złamał postanowienia rozejmu z Altmarku i wystąpił przeciwko Szwecji. Stolica Apostolska miała też spore nadzieje na zaangażowanie się Rzeczypospolitej w wojnę na terenie Rzeszy w związku z podróżą europejską królewicza Władysława. Nadzieje te 
podtrzymywano także później, gdy królewicz objął tron po śmierci ojca, Zygmunta III Wazy. Drugim ważkim elementem polityki papieskiej względem Rzeczypospolitej była stała obserwacja relacji polsko-moskiewskich i równolegle szwedzko-moskiewskich.

Polityka pierwszych lat panowania Władysława IV to między innymi starania Rzeczypospolitej o uzyskanie od papieża subsydiów na wojnę z Moskwą, Turcją i Szwecją, ustalenie planu walki z Turcją i koordynacji nią, zdobycie dyspensy potrzebnej do zawarcia małżeństwa z Elżbietą von Wittelsbach, próby oddziaływania poprzez dyplomację papieską na Habsburgów, by udzielili pomocy Polsce.

W pracy Dudy dobrze widać punkty zbieżne oraz całkowite rozmijanie się we wzajemnych oczekiwaniach Rzeczypospolitej i Stolicy Apostolskiej. Exempli gratia: kwestia zabiegów strony polskiej o małżeństwo władcy z Elżbietą. Oprócz starannie przeanalizowanej kwestii szwedzkiej i moskiewskiej poprzez pryzmat polityki papieskiej wobec Rzeczypospolitej, Autor pracy poświęcił sporo uwagi problematyce tureckiej. Chodzi tu oczywiście o starania Stolicy Apostolskiej o utworzenie ligi państw chrześcijańskich (nie tylko katolickich, bo myślano w swoim czasie także o Moskwie) przeciwko Imperium Otomańskiemu. Szeroki krąg państw, które miały zasilić wspólny front działań w wojnie antytureckiej, zmieniał się wraz z aktualną koniunkturą polityczną i przetasowaniem sił. Dość powiedzieć, że w latach 40. XVII wieku Stolica Apostolska działała wspólnie z dyplomatami Najjaśniejszej Republiki Wenecji. Dobrze na tym tle widać, jak racje stanu Rzeczypospolitej i Stolicy Apostolskiej rozmijały się na przykład w momentach „uspokojenia” na granicy polsko-tureckiej.

Tematem do dyskusji pozostają natomiast kwestie wyznaniowe dotyczące zabiegów dyplomacji papieskiej o utrzymanie unii brzeskiej, a także o podtrzymanie idei unii z Kościołem ormiańskim w Rzeczypospolitej. Zgodzić się wypadnie, że tematyka powyższa łączy się z historią polityki wewnętrznej Rzeczypospolitej, ale czy w istocie da się laboratoryjnym cięciem oddzielić ją od spraw międzynarodowych?

Marzeniem Stolicy Apostolskiej był powrót do stanu sprzed wielkiej schizmy, ponowna unia Kościołów - dość przypomnieć unię florencką czy próby zorientowania się co do możliwości przeprowadzenia unii w Moskwie (misja Possevina) - tymczasem unia z Kościołem ormiańskim miała przecież zasięg szerszy niż europejski. 
W zakończeniu przedstawianej tu rozprawy Autor wysunął wiele interesujących wniosków, często modyfikując interpretacje dotychczasowej historiografii. Pokazał także pewną ewolucję stosunku Rzymu do Rzeczypospolitej w kluczowych dla tej ostatniej sprawach międzynarodowych. Powyżej mowa była o Turcji, dodajmy jeszcze raz kwestie szczególnego zainteresowania dyplomacji papieskiej relacjami polsko-szwedzkimi. Mniej uwagi poświęcono Moskwie, natomiast główny ciężar działań dyplomacji papieskiej skierowany był na Rzeszę. Paweł Duda szczegółowo, rzetelnie opisując działalność dyplomacji papieskiej na dworze polskim, by pozyskać Wazów dla Ferdynanda II, w istocie stawia wniosek, który przeczy istniejącemu w historiografii (nie tylko polskiej) poglądowi o antyhabsburskiej postawie Urbana VIII.

Autor kończy dysertację słowami: „Zwieńczeniem wzajemnych animozji [nuncjusza Maria Filonardiego i króla Władysława IV - T.Ch.-H.] było wydalenie w 1643 roku z Polski nuncjusza Mario Filonardiego i zerwanie relacji polsko-papieskich. Nowy nuncjusz przybył do Polski dopiero po śmierci Urbana VIII, gdy tiarę przywdział Innocenty X" (Duda 2014: 370-371).

$\mathrm{Z}$ nieco innej perspektywy ujął omawiane zagadnienia Henryk Litwin w ciekawej rozprawie zatytułowanej Chwała Pótnocy. Rzeczpospolita w europejskiej polityce Stolicy Apostolskiej w pierwszej połowie XVII wieku (1599-1648).

Państwo papieskie, warto przypomnieć, charakteryzowało w owym czasie podwójne oblicze, była to bowiem zarazem Stolica Apostolska, a jednocześnie państwo o charakterze jak najbardziej świeckim. Odbiega to niewątpliwie od współczesnej wizji Stolicy Piotrowej. Najlepiej ten stan rzeczy określił znany i ceniony w świecie historyk włoski Paulo Prodi w znakomitej książce zatytułowanej Il sovrano pontefice. Un corpo e due anime: la monarchia papale nella prima età moderna (Bologna 1982, II wyd. 2006). Każda z części pracy Henryka Litwina poświęcona jest polityce innych papieży z uwypukleniem ich stosunku do Rzeczypospolitej w szerszej, ogólnoeuropejskiej perspektywie.

W części pierwszej znajduje się omówienie polityki papieża Klemensa VIII wobec Polski i Europy w latach 1599-1605. Zgodnie z koncepcją przedstawioną w rozdziale wstępnym, Autor rozpoczyna opis wydarzeń od roku 1599 - nie od początku pontyfikatu tego papieża, tj. od 1592 r. 
- jednakże w pierwszym podrozdziale przedstawia zarys całego pontyfikatu, łącznie ze szczegółowym sprawozdaniem z konklawe. Następnie omawia strukturę służby dyplomatycznej, urzędy kurialne i nuncjatury w krajach europejskich z czasów tego papieża, by przejść do analizy nuncjatury Claudia Rangoniego (1599-1605) i jego roli w polityce wobec Rzeczypospolitej.

Kolejne fragmenty pracy dotyczą opisu Rzeczypospolitej w polityce europejskiej Pawła V (1605-1621) oraz głównych kierunków polityki wobec Polski w kontekście innych działań międzynarodowych za nuncjatur Claudia Rangoniego (1605-1607), Francesca Simonetty (1606-1612), Lelia Ruiniego (1613-1614) i Francesca Diotalleviego (1614-1621).

W następnej części pokazana jest polityka Grzegorza XV (1621-1623), łączona z misjami dwóch nuncjuszy - Cosima de Torresa (1621-1622) oraz Giovanniego Battisty Lancellottiego (1623-1627).

Dalsza część rozprawy dotyczy działań Urbana VIII wobec Europy i Rzeczypospolitej oraz misji kilku nuncjuszy - Giovanniego Battisty Lancellottiego (druga część nuncjatury z lat 1623-1627), Antonia Santa Croce (1627-1630), Onorata Viscontiego (1630-1636) i Maria Filonardiego (1636-1643).

W końcowej części monografii Henryk Litwin przedstawia charakterystykę pontyfikatu Innocentego X w latach 1644-1648 oraz nuncjaturę Giovanniego de Torresa. W sposób interesujący i przekonujący zarazem Autor ukazuje pewną ewolucję planów związanych z Rzecząpospolitą w pierwszej połowie XVII wieku. Początkowo były to rewolucyjne wizje pozyskania Moskwy dla jedności Kościoła i przywrócenia stanu sprzed wielkiej schizmy czy projekt organizacji ligi antytureckiej, w której Rzeczpospolita miała odgrywać znaczącą rolę. Paweł V zmienił jednak plany Klemensa VIII: zaangażowany w wojnę trzydziestoletnią, zmuszony był do prowadzenia polityki defensywnej. Powrót do planów antytureckich wydawał się bardzo trudny. Klęska papiestwa w polityce europejskiej w sposób spektakularny dała o sobie znać po westfalskich negocjacjach pokojowych, z których Rzym został wyeliminowany.

W aktach dyplomatów papieskich widać wyraźnie długofalowe zainteresowanie polityką zagraniczną, ale też i wewnętrzną Rzeczypospolitej. Jak twierdzi autor rozprawy poświęconej tym zagadnieniom, Rzeczpospolita była dla Stolicy Apostolskiej najważniejszym sprzymierzeńcem 
w pierwszej połowie XVII wieku. „Papieże byli gotowi jej schlebiać, nazywać ją "przedmurzem chrześcijaństwa», «chlubą Północy», wspierać w walkach z innowiercami i dbać o wsparcie ze strony innych katolickich państw" (Litwin 2013: 301). Zmiana tego stanu spowodowana była pomniejszeniem roli papiestwa w europejskiej grze politycznej.

Zaprezentowane tu studia, zwłaszcza Henryka Litwina i Pawła Dudy, dobrze wpisują się w nurt badań wielu polskich ośrodków uniwersyteckich nad dyplomacją papieską. Autorzy analizują bogaty materiał archiwalny i biblioteczny powstały w wyniku działalności wysłanników Stolicy Apostolskiej czasów Jagiellonów, Stefana Batorego, Wazów, Jana III Sobieskiego, Sasów, Stanisława Augusta Poniatowskiego, a potem II Rzeczypospolitej.

Uwagę zwraca różnorodność analizowanej dokumentacji każdego kolejnego nuncjusza, jej znaczenie historyczne. Niezwykle ważne są m.in. cotygodniowe relacje dyplomatów o aktualnych wydarzeniach z Rzeczypospolitej przesyłane do papieskiego Sekretariatu Stanu. Tylko część z nich, co oczywiste, dotyczy Kościoła i spraw religijnych. Gros materiału jeszcze czeka na analizę naukową, stanowiąc wielkie wyzwanie badawcze i edytorskie. Zamknięta jest w nim fascynująca historia wielonarodowościowej, wielowyznaniowej i wielokulturowej Rzeczypospolitej, kraju związanego od początku swego bytu państwowego z chrześcijaństwem, ale szanującego różne obrzędy i religie, utrzymującego ścisłe więzi z całą Europą. Dotychczas ukazało się ponad trzydzieści tomów materiału archiwalnego ze zbiorów watykańskich. Opublikowanie całości dokumentów nuncjatury pozwoli na stworzenie pełniejszego, syntetycznego obrazu Rzeczypospolitej w jej relacjach nie tylko z Rzymem, ale też z innymi państwami europejskimi, pogłębiając wiedzę o relacjach naszego państwa z Kościołem ${ }^{5}$.

Teresa Chynczewska-Hennel

${ }^{5}$ Wyniki dotychczasowych studiów z tej dziedziny odzwierciedlają prace wielu badaczy opublikowane w: Chynczewska-Hennel, Wiszowata-Walczak 2012. 


\section{Literatura}

Chynczewska-Hennel T., (red.), 2003, „Acta Nuntiaturae Polonae”, t. XXV, Marius Filonardi (1635-1643), vol. 1 (12.02.1635-29.10.1636), Cracoviae.

Chynczewska-Hennel T., 2006a, Nuncjusz i król. Nuncjatura Maria Filonardiego w Rzeczypospolitej 1636-1643, Warszawa.

Chynczewska-Hennel T., (red.), 2006b, „Acta Nuntiaturae Polonae”, t. XXV, Marius Filonardi (1635-1643), vol. 2 (1.11.1636-31.10. 1637), Cracoviae.

Chynczewska-Hennel T., 2012, Rok 1643. Z królem i Rzeczypospolita, w: Wobec króla i Rzeczypospolitej. Magnateria w XVI-XVIII wieku, red. E. Dubas-Urwanowicz, J. Urwanowicz, Kraków, s. 143-152.

Chynczewska-Hennel T., Wiszowata-Walczak K., (red.), 2012, Nuncjatura Apostolska w Rzeczypospolitej, Białystok.

Duda P., 2014, Polityka zagraniczna Rzeczypospolitej w ocenie dyplomacji papieskiej w latach 1623-1535, [na prawach rękopisu].

Epistola ad Papam Urbanum VIII, 1864, w: Relacje nuncjuszów apostolskich i innych osób o Polsce od roku 1548 do 1690, wyd. E. Rykaczewski, Berlin.

Kuźmina D., 2013, Wazowie a Kościół w Rzeczypospolitej, Warszawa.

Litwin H., 2013, Chwała Pólnocy. Rzeczpospolita w europejskiej polityce Stolicy Apostolskiej w pierwszej połowie XVII wieku (1599-1648), Lublin.

Prodi P., 1982, Il sovrano pontefice. In corpo e due anime: la monarchia papale nella prima età moderna, Bologna. 